\title{
Physiological responses of watercress to brackish waters and different nutrient solution circulation times ${ }^{1}$
}

\section{Respostas fisiológicas de agrião com águas salobras e diferentes tempos de circulação da solução nutritiva}

\author{
Camila Alves de Souza ${ }^{2}$; Alexsandro Oliveira da Silva ${ }^{3 *}$; Claudivan Feitosa de \\ Lacerda $^{3}$; Ênio Farias de França e Silva ${ }^{4}$; Marlos Alves Bezerra ${ }^{5}$
}

\section{Highlights:}

The use of brackish waters is an option for semi-arid regions.

Gas exchange in watercress decreases in water with $\mathrm{ECw}$ above $2.6 \mathrm{dS} \mathrm{m}^{-1}$.

Proline concentration increases with plant salinity.

\begin{abstract}
Water scarcity and the use of brackish water are the main challenges for agricultural development. In view of this, the present study proposes to examine physiological responses of the broadleaf-cress crop in an NFT hydroponics system according to the use of brackish water and nutrient solution circulation times. The treatments were distributed in a randomized block design with five water salinity levels (ECw: $0.6,1.6,2.6,3.6$ and $\left.4.6 \mathrm{dS} \mathrm{m}^{-1}\right)$ and two nutrient solution circulation times $(\mathrm{T} 1=10 \mathrm{~min}$ and $\mathrm{T} 2=15$ $\mathrm{min}$ ), totaling 10 treatments with four replicates, which resulted in 40 experimental plots. The following variables were analyzed: net photosynthetic rate, stomatal conductance, transpiration, leaf proline content, shoot moisture content, stem diameter and root length. The maximum observed photosynthetic rates were $20.9 \mathrm{mmol} \mathrm{m}^{-2} \mathrm{~s}^{-1}$ (T1) and $20.0 \mathrm{mmol} \mathrm{m}^{-2} \mathrm{~s}^{-1}(\mathrm{~T} 2)$. Maximum stomatal conductance was 0.44 $\mathrm{mol} \mathrm{m}^{-2} \mathrm{~s}^{-1}$, which decreased by $63.4 \%$ at the highest salinity level. The increasing ECw levels in both growing cycles evaluated reduced gas exchanges, stem diameter and root length. The nutrient solution circulation time of $15 \mathrm{~min}$ provided the most satisfactory results for the analyzed variables.
\end{abstract}

Key words: Nasturtium officinalis. Gas exchange. Electrical conductivity. Hydroponics.

\section{Resumo}

A escassez hídrica e o uso de água salobras são os principais desafios para o desenvolvimento agrícola. Diante disto o objetivo deste trabalho foi avaliar respostas fisiológicas da cultura do agrião d' água de folhas larga em sistema hidropônico NFT em função do uso de águas salobras e tempos de circulação da solução nutritiva. Os tratamentos foram distribuídos em delineamento em blocos casualizados, com cinco níveis de salinidade da água (CEa: 0,$6 ; 1,6 ; 2,6 ; 3,6$ e 4,6 dS m $\mathrm{m}^{-1}$ ) e dois tempos de circulação

\footnotetext{
1 Parte da Dissertação do primeiro autor, apresentada ao Programa de Pós-Graduação em Engenharia Agrícola, Universidade Federal do Ceará, UFC, Fortaleza, CE, Brasil.

2 M.e em Engenharia Agrícola, Centro de Ciências Agrárias, UFC, Fortaleza, CE, Brasil. E-mail: camilaifce2014@gmail.com

3 Profs., Drs., UFC, Fortaleza, CE, Brasil. E-mail: alexsandro@ufc.br; cfeitosa@ufc.br

4 Prof. Dr., Universidade Federal Rural de Pernambuco, UFRPE, Recife, Brasil. E-mail: enio.fsilva@ufrpe.br

5 Dr. Pesquisador, Empresa Brasileira de Pesquisa Agropecuária, EMBRAPA Agroindústria Tropical, Fortaleza, Brasil. E-mail: marlos.bezerra@embrapa.br
}

* Author for correspondence 
da solução nutritiva, $(\mathrm{T} 1=10$ e $\mathrm{T} 2=15 \mathrm{~min}$ ), totalizando 10 tratamentos com 4 repetições, resultando em 40 parcelas experimentais. As variáveis analisadas foram: taxa de fotossíntese líquida, condutância estomática, transpiração, teor foliar de prolina, teor de umidade da parte aérea das plantas, diâmetro do caule e comprimento das raízes. A máxima fotossíntese observada foi de $20,9 \mathrm{mmol} \mathrm{m}^{-2} \mathrm{~s}^{-1}$ (T1) e 20,0 mmol m $\mathrm{m}^{-2} \mathrm{~s}^{-1}$ (T2), para a condutância estomática foi $0,44 \mathrm{~mol} \mathrm{~m}^{-2} \mathrm{~s}^{-1}$ provocando decréscimo $63,4 \%$. O aumento dos níveis de $\mathrm{CEa}$, em ambos os ciclos de cultivo avaliados, reduziram os valores de trocas gasosas, diâmetro do caule e comprimento da raiz. O tempo de 15 min promoveu os resultados mais satisfatórios para as variáveis analisadas.

Palavras-chave: Nasturtium officinalis. Trocas gasosas. Condutividade elétrica. Hidroponia.

\section{Introduction}

Water scarcity and poor water quality are the main challenges for agricultural development. Thus, the search for technologies may be an option to broaden the water supply, allowing, for instance, the use of brackish water sources. The hydroponic technique represents an alternative for the use of these waters (Campos, Santos, Silva, Martins, \& Rolim, 2018), since plants in this system have a higher tolerance to salinity owing to the almost total absence of matric potential (F. V. Silva et al., 2013).

Some problems still need to be addressed before establishing the use of brackish waters in hydroponics. Irrigation frequency and nutrient solution circulation time are some of the little studied aspects due to the conventional use of fixed times in production, where 15-min intervals are commonly adopted (Martinez, 2016). However, variations in circulation time can be related to several factors, e.g., time of year (Silva, Soares, Silva, Santos, \& Klar, 2012), climatic conditions of the area, among others. In this respect, Campos et al. (2018) evaluated arugula production in a hydroponic system and observed an effect of different nutrient solution circulation conditions on the roots and water use efficiency of the plants, which demonstrates the importance of this factor.

Another relevant aspect are the salinity-stress conditions to which plants are subjected in a hydroponic environment, which cause physiological changes such as reduced water flow caused by decreased stomatal conductance and, consequently, reduced transpiration (Gonçalves et al., 2010).
Among the biochemical responses, proline production is noteworthy. Proline is an amino acid that accumulates in response to salt or water stresses in plants (Paulus, Dourado, Frizzone, \& Soares, 2010). However, plant species differ in biochemical and physiological responses (Chiconato, Sousa, Santos, \& Munns, 2019; Munns, 2011), especially depending on their growing environment. Despite this, changes and physiological disturbances in crops in hydroponic media have been little questioned, which has even led to comparisons with soil cultivation for plants such as watercress (Nasturtium officinalis), due to its recently studied production in hydroponic conditions. Therefore, further information is still required about the physiological aspects.

Watercress is a semi-perennial Brassicaceae that can be grown in water or soil. It is considered a culinary plant that can be used in salads or as a complement to other dishes (Filgueira, 2012). As stated by Lira et al. (2018), in hydroponic cultivation using of brackish water, watercress has its production variables such as fresh and dry matter reduced. However, this production varies depending on the type of brackish water used. According to Lira et al. (2019), watercress has a better response, in terms of fresh and dry matter, to chlorinated calcium water, despite its high salinity $\left(4.71 \mathrm{dS} \mathrm{m}^{-1}\right)$. Nonetheless, studies on the physiological aspects of this crop in saline medium are still incipient, warranting greater attention to complement the information existing thus far.

In view of the above situation, this study was undertaken to examine the physiological responses 
of the broadleaf-cress crop in an NFT hydroponics system according to the use of brackish water and nutrient solution circulation times.

\section{Material and Methods}

The experiment was carried out in a greenhouse at the Agrometeorological Station of the Department of Agricultural Engineering (DENA) at the Federal University of Ceará, Pici Campus, in Fortaleza CE, Brazil (3॰44'43.273" S and 38 34'56.650" W; $22 \mathrm{~m}$ above sea level). Climatic data were collected in the greenhouse throughout the experimental period by a portable meteorological station $(\mathrm{HOBO}$ data logger; temp/light/ext channel) that took readings every 30 min over $24 \mathrm{~h}$. Figure 1 shows the average, minimum and maximum temperature and relative humidity values obtained inside the protected environment during the two growing cycles. Average daily temperature ranged from 26.3 to $31.3{ }^{\circ} \mathrm{C}$ (first cycle) and from 26.9 to 32.3 ${ }^{\circ} \mathrm{C}$ (second cycle) and average relative humidity oscillated between 69.2 and $91.1 \%$ (first cycle) and 66.8 and $91.1 \%$ (second cycle).
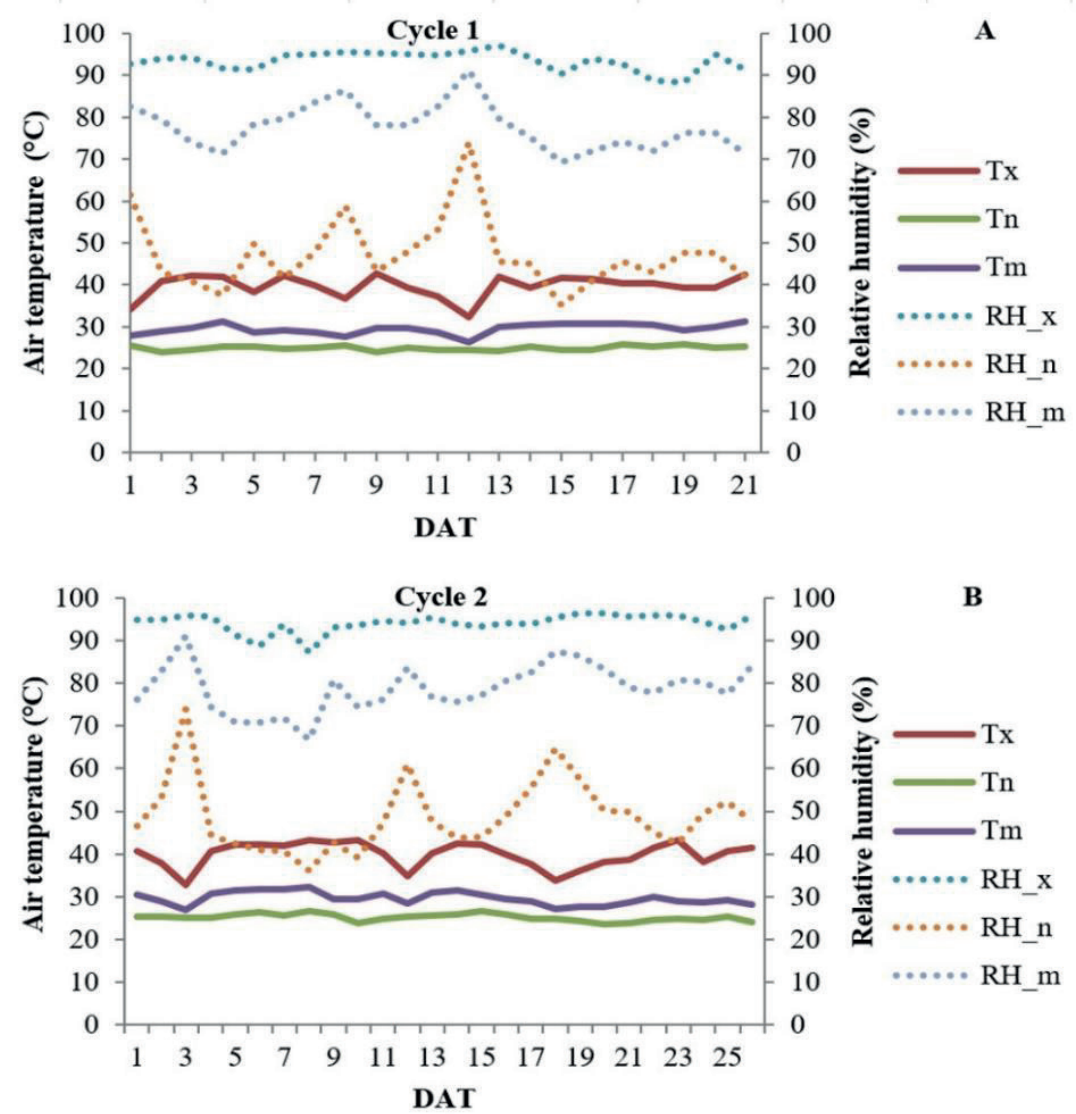

Figure 1. Maximum $(\mathrm{Tx})$, average $(\mathrm{Tm})$ and minimum $(\mathrm{Tn})$ air temperature and maximum ( $\left.\mathrm{RH}_{-} \mathrm{x}\right)$, average $\left(\mathrm{RH} \_\mathrm{m}\right)$ and minimum $\left(\mathrm{RH} \_\mathrm{n}\right)$ relative humidity in the first (A) and second (B) production cycles in the greenhouse.

A NFT (laminar nutrient flow technique) block design with a $5 \times 2$ factorial arrangement hydroponic system was adopted in which the represented by five levels of salinity in the water treatments were distributed in a randomized- used in the preparation of the nutrient solution (0.6, 
1.6, 2.6, 3.6 and $\left.4.6 \mathrm{dS} \mathrm{m}^{-1}\right)$ and two nutrient solution circulation times $(\mathrm{T} 1=10 \mathrm{~min}$ and $\mathrm{T} 2=15 \mathrm{~min}$ ). Four replicates were used, totaling 40 experimental plots. The salinity levels were obtained by adding sodium chloride $(\mathrm{NaCl})$ to the supply water $(0.6 \mathrm{dS}$ $\left.\mathrm{m}^{-1}\right)$. After each water salinity level with $\mathrm{NaCl}$ was obtained, the macro- and micronutrients to prepare the nutrient solution were added, as recommended by Furlani (1998). Both nutrient solution circulation times were programmed via timer for 10 and $15 \mathrm{~min}$ of circulation.

The experimental plot consisted of a profile in an independent NFT system (Soares et al., 2009) composed of 2.7-m-long PVC tubes (100-mm diameter with 2.5 -cm-radius holes) with plants and profiles spaced $0.25 \mathrm{~m}$ apart, totaling ten holes where nine plants were grown per profile. The profiles were installed in the structure at an average height of $0.85 \mathrm{~m}$, with an inclination of $3.0 \%$, to promote drainage. The nutrient solution was stored in 50-L drums and conducted through the PVC pipe to be injected into the profile through microtubes at a flow rate of $1.5 \mathrm{~L} \mathrm{~min}^{-1}$.

Broadleafcress(Nasturtium officinale) seeds were sown in trays containing coconut fiber substrate. At eight days after sowing (DAS), seedlings received a nutrient solution as recommended by Furlani (1998), diluted by $50 \%$. At 10 DAS, the plants were thinned, leaving one seedling per cell. At 30 DAS, seedlings were transplanted to hydroponic profiles where the saline treatments were started.

At 6, 10, 14, 20 and 25 days after transplanting (DAT), in both production cycles, the growth traits of root length $(\mathrm{cm})$ and stem diameter $(\mathrm{cm})$ were measured using a graduated ruler and a digital caliper, respectively. At 20 DAT, gas exchanges were determined on fully expanded leaves. Net photosynthetic rate $(A)$, stomatal conductance $(g s)$ and transpiration $(E)$ were measured by a portable photosynthesis meter (LI-6400XR, Liquor, USA) based on the $\mathrm{CO}_{2}$ concentration and photosynthetically active radiation of the environment.

The proline content was determined following the methodology of Bates, Waldren and Teare (1973). Calculations were made using the equation obtained for the standard curve made with L-proline as reference, and results were expressed in $\mu \mathrm{mol}$ proline $\mathrm{g}^{-1}$ of dry matter.

The plant shoot moisture content (U) was calculated using equation 1 (A. O. Silva et al., 2012), as shown next:

$U=\left(\frac{S F M-S D M}{S F M}\right) \times 100$

where U - shoot moisture (\%); SFM - shoot fresh matter (g); and SDM - shoot dry matter (g).

Data were subjected to the normality test, followed by analysis of variance (F-test). When significant effects were detected, regression analysis was performed for quantitative data and Fisher's t test for qualitative date at $1 \%(\mathrm{p}<0.01)$ and $5 \%$ $(p<0.05)$ probability, using SISVAR software version 5.3.

\section{Results and Discussion}

The leaf gas exchange, proline content and moisture content of the watercress crop in the two cycles are described in Table 1. In the first cycle, there was a significant effect of the salinity factor on photosynthesis $(A)$, transpiration $(E)$, stomatal conductance $(g s)$ and proline content. For the time factor, only the plant moisture content (U) was influenced. The salinity $\times$ time interaction influenced $A$ only. In the second cycle, the salinity factor affected the $U$ and proline variables. There was a salinity $\times$ time interaction effect for the $E$ variable. 
Table 1

Summary of analysis of variance for the variables of photosynthesis $(A)$, transpiration $(E)$, stomatal conductance (gs) and proline and moisture $(U)$ contents in watercress grown in brackish water under nutrient solution circulation times, in two growing cycles

\begin{tabular}{ccccccc}
\hline SV & DF & $A$ & $E$ & $g s$ & Proline & U \\
\hline & & & Cycle 1 & & \\
Block & 3 & $12.32^{\text {ns }}$ & $0.16^{\text {ns }}$ & $0.023^{\text {ns }}$ & $5460.47^{\text {ns }}$ & $2.64^{\text {ns }}$ \\
Salinity & 4 & $86.23^{* *}$ & $4.29^{* *}$ & $0.094^{*}$ & $66229.19^{* *}$ & $23.28^{\text {ns }}$ \\
Time & 1 & $2.86^{\text {ns }}$ & $0.5^{\text {ns }}$ & $0.044^{\text {ns }}$ & $282.54^{\text {ns }}$ & $12.99^{* *}$ \\
Salinity*Time & 4 & $10.94^{*}$ & $0.58^{\text {ns }}$ & $0.0089^{\text {ns }}$ & $1917.57^{\text {ns }}$ & $3.36^{\text {ns }}$ \\
Residual & 27 & 3.92 & 0.42 & 0.028 & 3060.86 & 1.37 \\
\hline CV $(\%)$ & 11.23 & 14.83 & 50.69 & 25.91 & 1.37 \\
\hline Block & 3 & $412.74^{* *}$ & $22.53^{* *}$ & $0.082^{\text {ns }}$ & $2785.37^{\text {ns }}$ & $1.07^{\text {ns }}$ \\
Salinity & 4 & $3.11^{\text {ns }}$ & $5.16^{\text {ns }}$ & $0.188^{\text {ns }}$ & $8094.00^{*}$ & $16.54^{*}$ \\
Time & 1 & $8.46^{\text {ns }}$ & $2.43^{\text {ns }}$ & $0.05^{\text {ns }}$ & $4814.73^{\text {ns }}$ & $1.98^{\text {ns }}$ \\
Salinity*Time & 4 & $1.67^{\text {ns }}$ & $13.26^{* *}$ & $0.107^{\text {ns }}$ & $2724.73^{\text {ns }}$ & $1.25^{\text {ns }}$ \\
Residual & 27 & 6.77 & 2.78 & 0.104 & 2871.85 & 5.09 \\
\hline CV $(\%)$ & 7.71 & 25.45 & 44.09 & 34.23 & 2.62 \\
\hline
\end{tabular}

$\mathrm{SV}$ - source of variation; DF - degrees of freedom; CV - coefficient of variation; ${ }^{\text {ns }}$ - not significant, $* *, *$ - significant at $1 \%$ and $5 \%$ by the $\mathrm{F}$ test.

The effects of salinity on gas exchange in the first cycle are illustrated in Figure 2. The interaction effect between salinity and time for $A$ was significant (Figure 2A), and the regression model that best fitted the data was the quadratic type. According to this model, the maximum $A$ in T1 and T2 was achieved at the salinity levels of 1.9 and $2.2 \mathrm{dS} \mathrm{m}^{-1}$, which provided the photosynthetic rates of 20.9 mmol and $20.0 \mathrm{mmol} \mathrm{m}^{-2} \mathrm{~s}^{-1}$, respectively. At the highest salinity level $\left(4.6 \mathrm{dS} \mathrm{m}^{-1}\right), A$ decreased by 52.8 and $29.9 \%$ in $\mathrm{T} 1$ and $\mathrm{T} 2$, respectively. In the comparison of means, a significant difference was observed between the circulation times at $4.6 \mathrm{dS} \mathrm{m}^{-1}$ salinity, with higher means obtained in T2. This may be related to osmotic stress caused by the excess of salts, which induces an increase in leaf temperature and stomatal closure, reducing the photosynthetic process (Taiz, Zeiger, Møller, \& Murphy, 2017). 

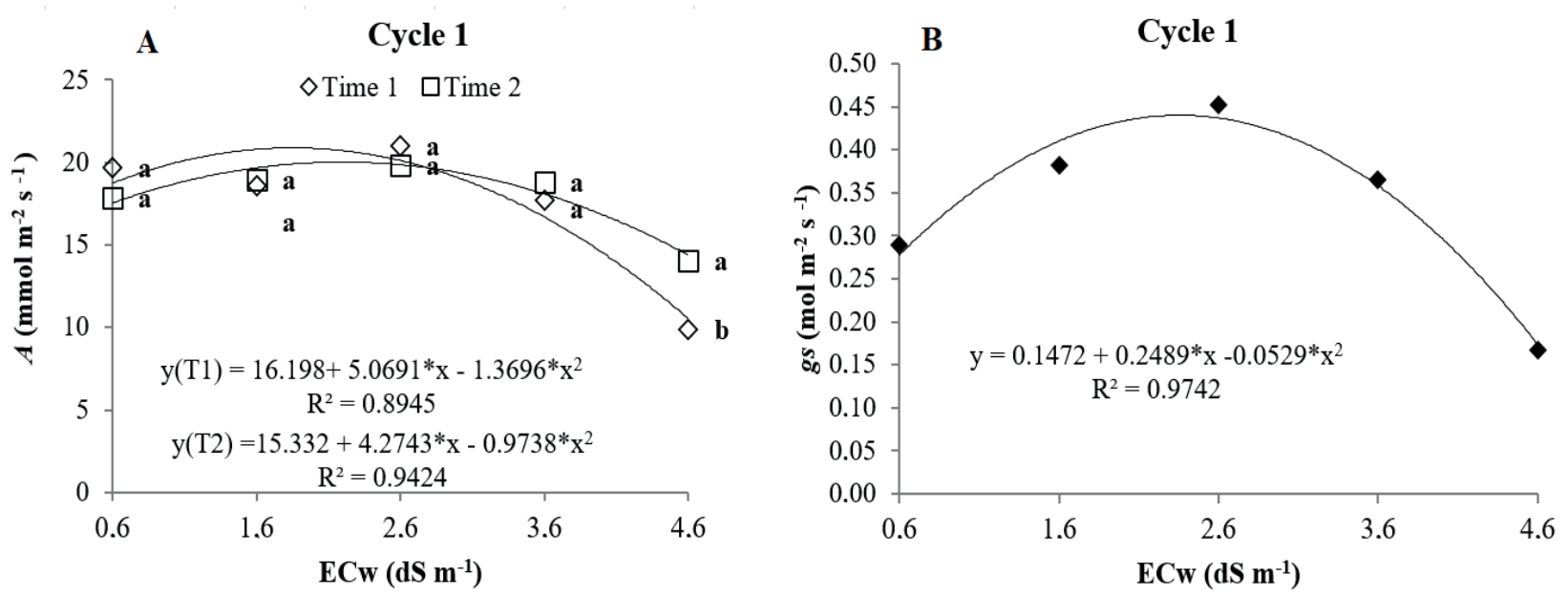

Figure 2. Mean values of the salinity $\times$ time interaction effect on photosynthesis $-A(\mathrm{~A})$ and the isolated factor of salinity on stomatal conductance - $g s(\mathrm{~B})$ for the watercress crop in cycle 1.

*: significant at $5 \%$ by the $\mathrm{F}$ test.

Stomatal conductance (Figure 2B) responded quadratically, with the highest value $\left(0.4 \mathrm{~mol} \mathrm{~m}^{-2} \mathrm{~s}^{-1}\right)$ found at the $\mathrm{ECw}$ of $2.4 \mathrm{dS} \mathrm{m}^{-1}$ and the lowest at 4.6 $\mathrm{dS} \mathrm{m}^{-1}$, representing a $63.4 \%$ decrease. According to Oliveira et al. (2016), a reduction in $g s$ may be associated with the regulation of water absorption by plants in conjunction with nutrient absorption, under stress conditions. Plants close their stomata in an effort to reduce water loss through transpiration, resulting in a lower photosynthetic rate, which is a major cause of reduced growth in species subjected to salinity stress (F. V. Silva et al., 2013).

Salinity stress causes changes in the water status of plants, inducing stomatal closure to limit the entry of $\mathrm{CO}_{2}$. In addition, high concentrations of ions such as $\mathrm{Na}^{+}$and $\mathrm{Cl}^{-}$are the main causes of damage to enzyme and membrane structures, which indirectly interferes with photosynthesis (F. L. B. Silva et al., 2011). Almeida, Aragão, Sousa, Bezerra and Silva (2018) examined the yield of the radish crop under different water tables and observed a reduction in photosynthetic rate in the treatments under greater stress due to excess water in the plants. Those authors also found that stomatal conductance has a direct relationship with transpiration, whereby transpiration rate decreases as the plants close their stomata, reducing the loss of water to the atmosphere.

For $E$, the quadratic model best fit the isolated effect of salinity in the first cycle (Figure 3A) and the interaction between salinity and nutrient solution circulation time in the second cycle (Figure 3B). However, maximum transpiration in the first cycle was $5.0 \mathrm{mmol} \mathrm{m}^{-2} \mathrm{~s}^{-1}$ at the ECW of $2.0 \mathrm{dS}$ $\mathrm{m}^{-1}$, with a $37.8 \%$ loss occurring when the highest $\mathrm{ECw}$ level was used. In response to the salinity $\times$ time interaction, the highest $E\left(8.7 \mathrm{mmol} \mathrm{m}^{-2} \mathrm{~s}^{-1}\right)$ occurred at the $\mathrm{ECW}$ of $2.6 \mathrm{dS} \mathrm{m}^{-1}$ in $\mathrm{T} 1$, which decreased by $48.6 \%$ at the $\mathrm{ECw}$ of $4.6 \mathrm{dS} \mathrm{m}^{-1}$. In $\mathrm{T} 2$, the lowest values were observed at the $\mathrm{ECW}$ of 2.6 and $4.6 \mathrm{dS} \mathrm{m}^{-1}$. 

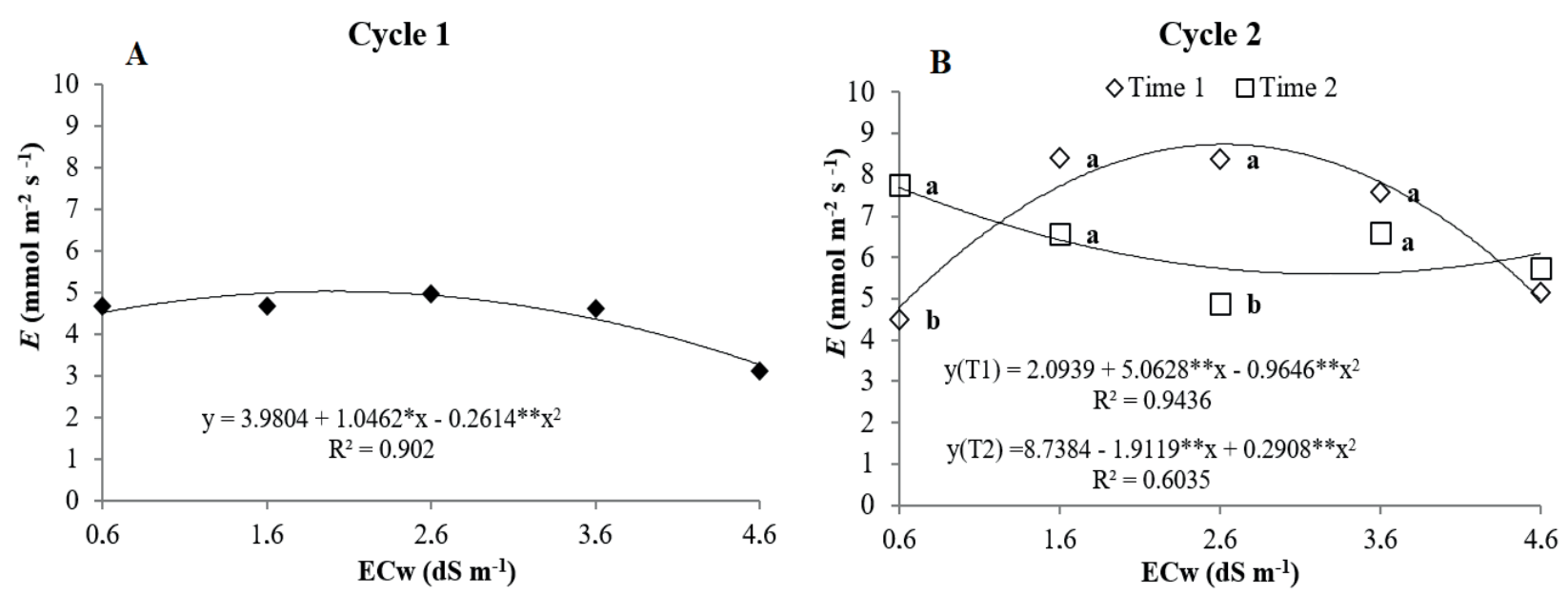

Figure 3. Transpiration as a function of the isolated effect of salinity (A) in cycle 1 and interaction between salinity and nutrient solution circulation time (B) in cycle 2 of the watercress crop.

** and *: significant at 1 and $5 \%$ by the $\mathrm{F}$ test.

Because watercress is a temperate-climate plant, it has no transpiration control and loses water easily, which characterizes its inefficiency. At mild temperatures, the plant is turgid, loses little water and transpires less, whereas at high temperatures, as in the present study $\left(31.3^{\circ} \mathrm{C}\right.$ in the first cycle and $32.3{ }^{\circ} \mathrm{C}$ in the second cycle), greater transpiration is observed. As described by Taiz et al. (2017), optimal temperatures for $\mathrm{C} 3$ plants are between 20 and $25^{\circ} \mathrm{C}$. The authors went on to mention that, in low temperature conditions, $\mathrm{C} 3$ plants exhibit low photorespiration, becoming more productive.

Figure 4 shows the isolated effect of salinity on the proline content, in both cultivation cycles. The quadratic model provided the best fit to this variable. In the first cycle, the proline content was $61.9 \%$ higher at the highest salinity level in relation to the lowest ECw. In the second cycle, the maximum proline value was $178.4 \mu \mathrm{mol} \mathrm{g}^{-1} \mathrm{DM}$ at the $\mathrm{ECw}$ of $3.2 \mathrm{dS} \mathrm{m}^{-1}$, which represents a $34.4 \%$ increase when compared with lowest ECw value. This response shown by proline can be considered a regulatory mechanism when the plant is under stress, whereby the plant synthesizes it in greater quantities. In other words, proline production increases along with the amount of salt. However, lower values were observed in the second cycle, indicating a reduction in the stress caused by the salts. 

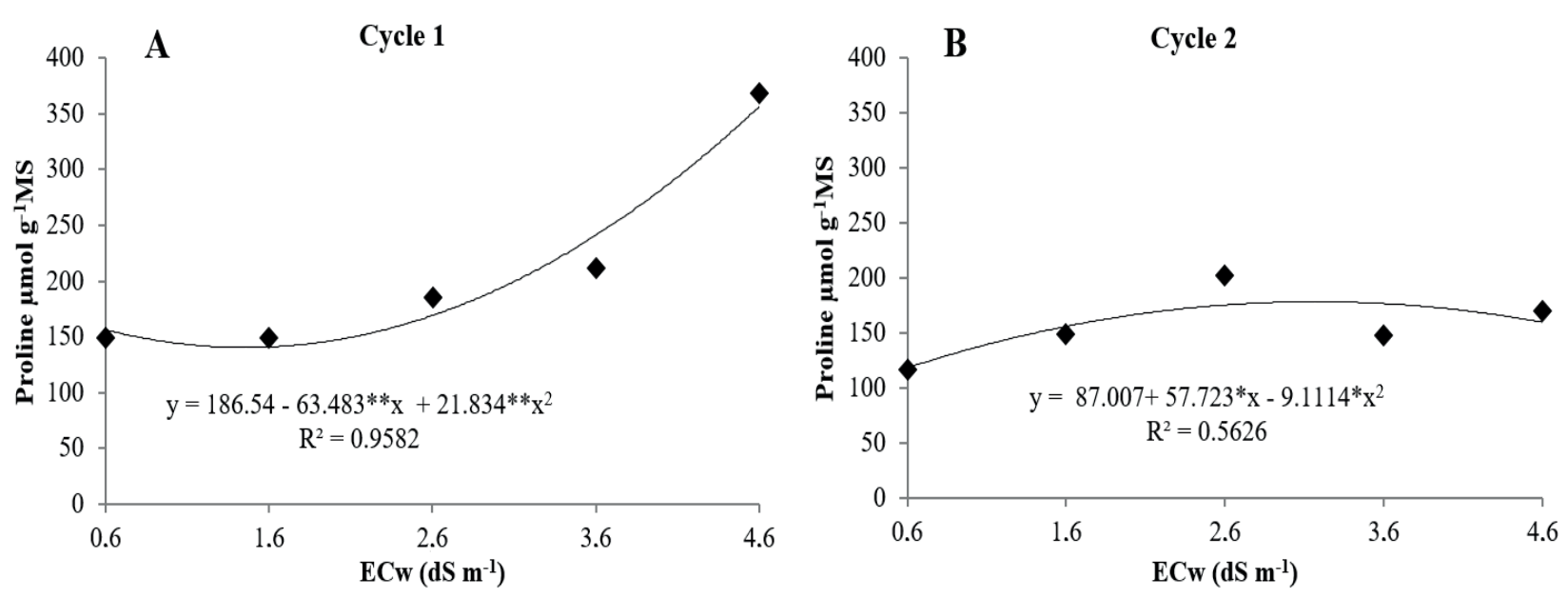

Figure 4. Proline as a function of salinity in cycles 1 (A) and 2 (B) in the watercress crop. ** and *: significant at 1 and $5 \%$ by the $\mathrm{F}$ test.

Paulus et al. (2010) evaluated the proline content of lettuce and found that water salinity had a significant effect on the plants, considering that this amino acid is an indicator of stress. Sarabi, Bolandnazar, Ghaderi and Ghashghaie (2017) studied the physiological responses of melon to salinity stress and showed that proline accumulation was highest in the most severe salinity treatments. According to those authors, in more sensitive melon varieties, proline also accumulated, although this accumulation was lower and their biomass also decreased more markedly. The increase in proline in tolerant melon varieties possibly supports the idea that proline neutralizes osmotic stress caused by salinity stress, providing these varieties with greater tolerance to that stress. Hannachi and Van Labeke (2018) showed, in eggplant seedlings, that the varieties most sensitive to salinity stress had a higher proline content. Therefore, the results of these authors support the idea that proline is an indicator of stress.

Figure 5 shows the moisture content (U) of the plants in the two growing cycles. In the first cycle (Figure 5A), the average plant $U$ values were evaluated as a function of the nutrient solution circulation times. The use of $\mathrm{T} 2$ provided the highest mean $(86.3 \%)$ among the observed values, which may have been due to the longer circulation time. In the second cycle (Figure 5B), the best fitting model was the quadratic model, with the maximum $\mathrm{U}$ observed at the salinity level $1.5 \mathrm{dS} \mathrm{m}^{-1}$, which declined by $2.1 \%$ at the $\mathrm{ECw}$ of $4.6 \mathrm{dS} \mathrm{m}^{-1}$. 

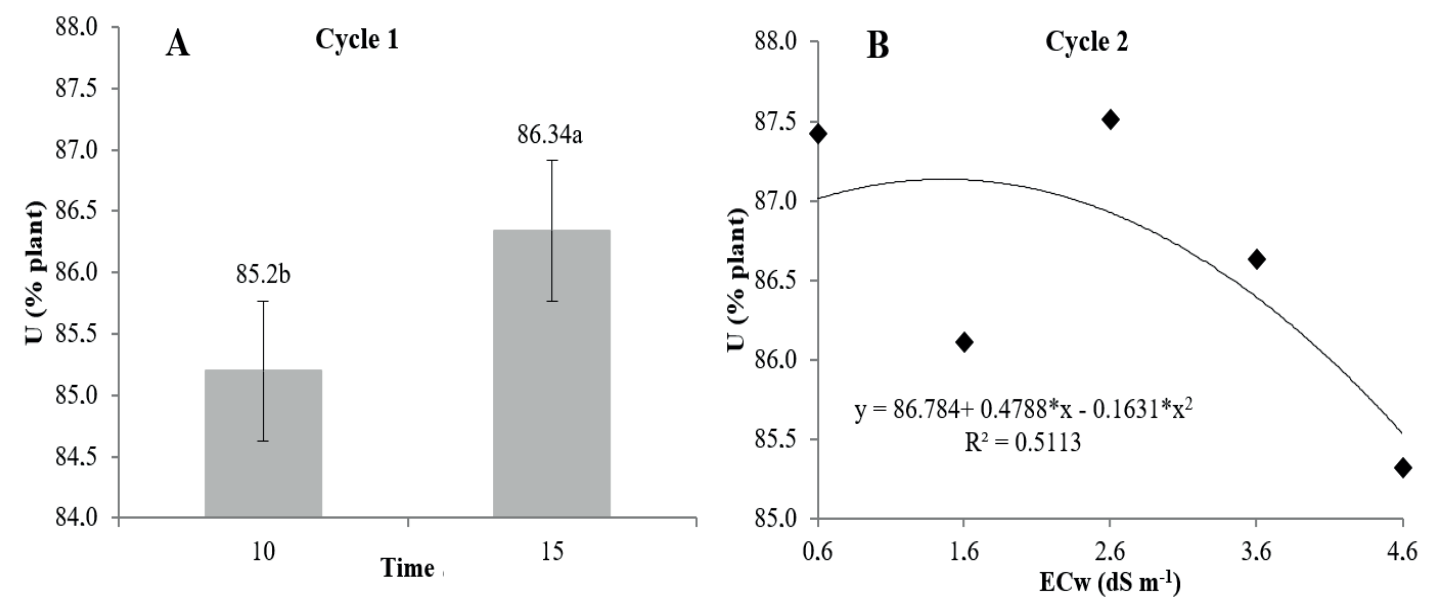

Figure 5. Variation of moisture content as a function of salinity levels in cycle 1 for the isolated factor of time (A) and in cycle 2 for the isolated factor of salinity (B) in the broad-leaved cress crop.

** and *: significant at 1 and $5 \%$ by the $\mathrm{F}$ test.

In the arugula crop, A. O. Silva et al. (2012) found an average plant moisture value of $85.4 \%$ in brackish waters and $84.8 \%$ with the addition of $\mathrm{NaCl}$ to desalinated water $\left(0.5 \mathrm{dS} \mathrm{m}^{-1}\right)$. Soares, Duarte, Silva and Jorge (2010) worked with the combination of fresh and brackish water in the lettuce crop and observed that as they increased the salinity of the replacement water, the water content in the shoots decreased, i.e., the plants lost water. Campos et al. (2018) investigated the arugula crop in a hydroponic system and reported that the water content of the plants decreased up to $8.1 \%$ in the salinity range of 1.5 to $9.0 \mathrm{dS} \mathrm{m}^{-1}$.
According to analysis of variance (Table 2), stem diameter (SD) was significantly influenced by the salinity factor at 14 and 20 DAT in the first cycle and at 14, 20 and 25 DAT in the second cycle. Nutrient solution circulation time influenced SD in the second cycle at 14 DAT. Root length (RL) was influenced in the first cycle by the isolated factors at 10 and 14 DAT and by the interaction at 14 DAT. In the second cycle, there was an isolated effect of salinity on RL at all evaluated times, except at 6 and 20 DAT. 
Table 2

Summary of analysis of variance for the growth variables of stem diameter (SD) and root length (RL) in watercress grown in brackish water under nutrient solution circulation times, in two growing cycles

\begin{tabular}{|c|c|c|c|c|c|c|}
\hline \multirow{4}{*}{ SV } & \multirow{4}{*}{ DF } & \multicolumn{5}{|c|}{ Mean square } \\
\hline & & \multicolumn{4}{|c|}{ Stem diameter } & \multirow[b]{2}{*}{$25 \mathrm{DAT}$} \\
\hline & & $6 \mathrm{DAT}$ & $10 \mathrm{DAT}$ & 14 DAT & $20 \mathrm{DAT}$ & \\
\hline & & \multicolumn{5}{|c|}{ Cycle 1} \\
\hline Block & 3 & $0.00043^{\text {ns }}$ & $0.00012^{\text {ns }}$ & $0.00015^{\mathrm{ns}}$ & $0.00144^{\mathrm{ns}}$ & - \\
\hline Salinity & 4 & $0.00031^{\mathrm{ns}}$ & $0.00033^{\mathrm{ns}}$ & $0.0062^{* *}$ & $0.00730^{* *}$ & - \\
\hline Time & 1 & $0.00081^{\mathrm{ns}}$ & $0.00016^{\mathrm{ns}}$ & $0.0000^{\mathrm{ns}}$ & $0.00100^{\mathrm{ns}}$ & - \\
\hline Salinity*Time & 4 & $0.00024^{\mathrm{ns}}$ & $0.00041^{\mathrm{ns}}$ & $0.00045^{\mathrm{ns}}$ & $0.00094^{\mathrm{ns}}$ & - \\
\hline Residual & 27 & 0.00020 & 0.00044 & 0.00065 & 0.00090 & - \\
\hline \multirow[t]{2}{*}{$\mathrm{CV}(\%)$} & & 7.86 & 9.65 & 9.81 & 8.85 & - \\
\hline & & \multicolumn{5}{|c|}{ Cycle 2} \\
\hline Block & 3 & $0.00032^{\text {ns }}$ & $0.000143^{\mathrm{ns}}$ & $0.000203^{\text {ns }}$ & $0.00031^{\mathrm{ns}}$ & $0.00056^{\mathrm{ns}}$ \\
\hline Salinity & 4 & $0.00029^{\mathrm{ns}}$ & $0.000794^{\mathrm{ns}}$ & $0.001341^{*}$ & $0.00140^{*}$ & $0.00247^{* *}$ \\
\hline Time & 1 & $0.00001^{\mathrm{ns}}$ & $0.000360^{\mathrm{ns}}$ & $0.002103^{*}$ & $0.00081^{\mathrm{ns}}$ & $0.000003^{\mathrm{ns}}$ \\
\hline Salinity*Time & 4 & $0.00007^{\mathrm{ns}}$ & $0.000016^{\mathrm{ns}}$ & $0.000284^{\mathrm{ns}}$ & $0.00074^{\mathrm{ns}}$ & $0.00095^{\mathrm{ns}}$ \\
\hline Residual & 27 & 0.00015 & 0.000153 & 0.00034 & 0.00045 & 0.00037 \\
\hline \multirow[t]{3}{*}{ CV (\%) } & & 9.80 & 7.37 & 9.42 & 8.79 & 6.57 \\
\hline & & \multicolumn{5}{|c|}{ Root length } \\
\hline & & \multicolumn{5}{|c|}{ Cycle 1} \\
\hline Block & 3 & $0.22^{\mathrm{ns}}$ & $0.27^{\mathrm{ns}}$ & $0.067^{\mathrm{ns}}$ & $0.034^{\mathrm{ns}}$ & - \\
\hline Salinity & 4 & $1.86^{\mathrm{ns}}$ & $0.69^{*}$ & $2.28^{* *}$ & $4.19^{\mathrm{ns}}$ & - \\
\hline Time & 1 & $0.034^{\mathrm{ns}}$ & $0.5^{\mathrm{ns}}$ & $1.19^{*}$ & $0.087^{\mathrm{ns}}$ & - \\
\hline Salinity*Time & 4 & $1.28^{\mathrm{ns}}$ & $0.26^{\mathrm{ns}}$ & $0.95^{* *}$ & $0.44^{\mathrm{ns}}$ & - \\
\hline Residual & 27 & 0.15 & 0.12 & 0.18 & 0.25 & - \\
\hline \multirow[t]{2}{*}{$\mathrm{CV}(\%)$} & & 7.66 & 6.18 & 6.90 & 7.36 & - \\
\hline & & \multicolumn{5}{|c|}{ Cycle 2} \\
\hline Block & 3 & $0.21^{\mathrm{ns}}$ & $0.049^{\text {ns }}$ & $0.11^{\mathrm{ns}}$ & $0.37^{\mathrm{ns}}$ & $0.11^{\mathrm{ns}}$ \\
\hline Salinity & 4 & $0.49^{\mathrm{ns}}$ & $0.76^{* *}$ & $0.69^{* *}$ & $0.16^{\mathrm{ns}}$ & $10.99^{* *}$ \\
\hline Time & 1 & $0.012^{\mathrm{ns}}$ & $0.082^{\mathrm{ns}}$ & $0.16^{\mathrm{ns}}$ & $0.00002^{\mathrm{ns}}$ & $1.47^{\mathrm{ns}}$ \\
\hline Salinity*Time & 4 & $0.11^{\mathrm{ns}}$ & 0.21 & $0.14^{\mathrm{ns}}$ & $0.38^{\mathrm{ns}}$ & $1.25^{\mathrm{ns}}$ \\
\hline Residual & 27 & 0.08 & 0.10 & 0.11 & 0.22 & 0.56 \\
\hline CV (\%) & & 9.30 & 9.01 & 8.89 & 11.27 & 11.75 \\
\hline
\end{tabular}

$\mathrm{SV}$ - source of variation; DF - degrees of freedom; CV - coefficient of variation; ${ }^{\text {ns }}$ - not significant, $* *, *-$ significant at $1 \%$ and $5 \%$ by the $\mathrm{F}$ test. 
In the first cycle (Figure 6A), the quadratic model best fitted the SD data at 14 DAT, with the lowest values observed at the $\mathrm{ECW}$ of $1.6 \mathrm{dS} \mathrm{m}^{-1}$, whereas the linear model was best-fitting at 20 DAT, with a reduction of $0.94 \mathrm{~cm}_{\text {plant }}{ }^{-1}$ occurring with each unitary increase in ECw. In the second cycle (Figure $6 \mathrm{~B})$, at $14 \mathrm{DAT}$, the best fitting regression model for $\mathrm{SD}$ was the quadratic type, with a maximum growth of $0.20 \mathrm{~cm}$ observed at the ECw of $0.6 \mathrm{dS} \mathrm{m} \mathrm{m}^{-1}$, which decreased by $10 \%$ at the ECw of $3.6 \mathrm{dS} \mathrm{m}^{-1}$. At 20 and 25 DAT, SD decreased linearly by 0.80 and $0.44 \mathrm{~cm}$ plant $^{-1}$, respectively, with each unitary increase in $\mathrm{ECw}$. An excess of salts hinders water and nutrient absorption by the plant, contributing to the decrease in stem growth. R. S. S. Santos et al. (2010) examined the effect of salinity on the development of lettuce in a hydroponic system and found a linear reduction in plant production with increased salinity.

A decrease in SD was also described by Albuquerque et al. (2016), who evaluated the growth and tolerance of cucumber to salinity stress. Those authors found that salinity influenced stem diameter in the crop, which decreased as the salt concentrations were raised. Lima et al. (2015) also observed that the SD of eggplant was influenced by the increase in the salinity of the irrigation water. This reduction can be caused by high concentrations of salts, which interact negatively with the physiology of plants and promote harmful ionic, osmotic and nutritional interactions, affecting their growth and biomass accumulation (Taiz \& Zeiger, 2013).
Figure $6 \mathrm{C}$ shows the average $\mathrm{SD}$ in the second cycle at 14 DAT as a function of the nutrient solution circulation times. The use of $\mathrm{T} 2$ provided greater growth in SD $(0.20 \mathrm{~cm}$, on average). This response may have been due to the longer circulation time, which made smaller volumes of water available per day, possibly stimulating growth and reducing the stress caused by excess water in $\mathrm{T} 1$.

According to the regression analyses for RL, the quadratic and linear models best fit the data for isolated effect of salinity in the evaluation periods and for the salinity $\times$ time interaction effect in the first (6 and 10 DAT) and second (10.1 and 25 DAT) cycles (Figure 7). The maximum root growth in the first cycle at 6 DAT was $5.4 \mathrm{~cm}$ plant $^{-1}$ at the ECw of $1.4 \mathrm{dS} \mathrm{m}^{-1}$, which dropped by $13.2 \%$ at the $\mathrm{ECw}$ of $4.6 \mathrm{dS} \mathrm{m}^{-1}$. At $10 \mathrm{DAT}$, RL was $5.9 \mathrm{~cm}_{\text {plant }}{ }^{1}$ at the $\mathrm{ECw}$ of $2.0 \mathrm{dS} \mathrm{m}^{-1}$, which would decrease by $12 \%$ at the $\mathrm{ECw}$ of $4.6 \mathrm{dS} \mathrm{m}^{-1}$ (Figure $8 \mathrm{~A}$ ). At 14 DAT (Figure 7B) in the first cycle, there was an interaction effect between $\mathrm{ECw}$ and nutritional circulation time for RL. In T1, a linear reduction of $0.34 \mathrm{~cm}$ occurred with each unitary increase in $\mathrm{ECw}$, whereas in $\mathrm{T} 2$ the maximum value found was $6.85 \mathrm{~cm}^{2}$ at the $\mathrm{ECw}$ of $0.9 \mathrm{dS} \mathrm{m}^{-1}$, which declined by $21.6 \%$ decrease at the ECw of $4.6 \mathrm{dS} \mathrm{m}^{-1}$. When we compare the times, it is notable that a difference was only present at the salinity level of $3.6 \mathrm{dS} \mathrm{m}^{-1}$, and the highest value was found with $\mathrm{T} 2$. 

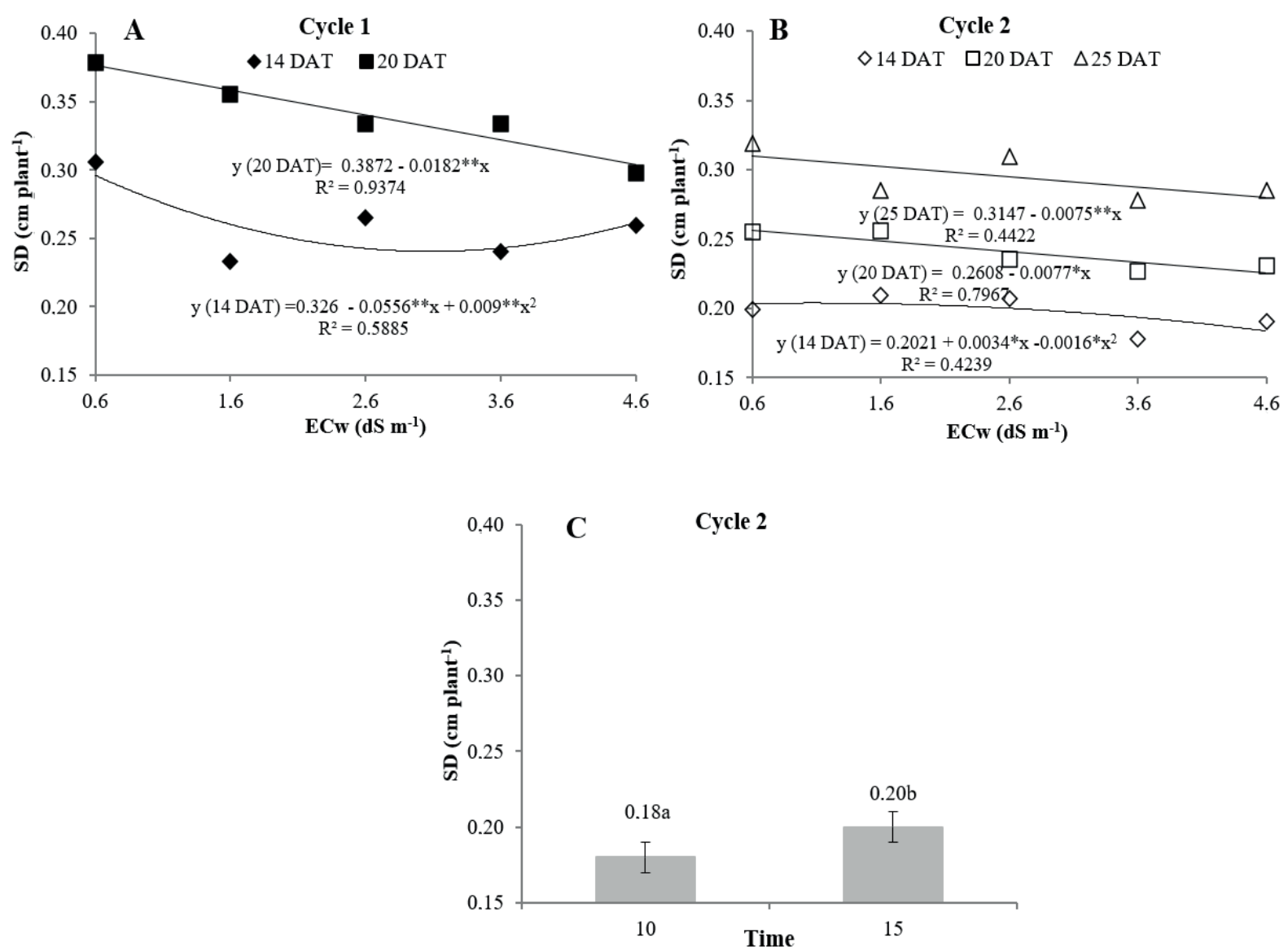

Figure 6. Stem diameter as a function of the isolated effect of water salinity in cycles 1 (A) and 2 (B) and as a function of nutrient solution circulation time $(C)$ in the watercress crop.

** and *: significant at 1 and $5 \%$ by the $\mathrm{F}$ test.

In cycle 2, at 10 and 14 DAT (Figure 7C), the water salinity levels that increased RL were 1.8 and $1.7 \mathrm{dS} \mathrm{m} \mathrm{m}^{-1}$, respectively, providing $\mathrm{RL}$ values of 3.7 and $4.0 \mathrm{~cm}$, which represented $17 \%$ and $11 \%$ greater lengths in relation to those obtained at the highest ECw. At 25 DAT, as ECw was increased, RL decreased linearly, by $0.63 \mathrm{~cm}$. According to
Mohammad, Shibli and Ajouni (1998), an increase in salinity is accompanied by a decrease in root length, which was observed in the present results. D. P. Santos et al. (2016) also found that the length of beetroot was negatively affected by increasing salinity. 

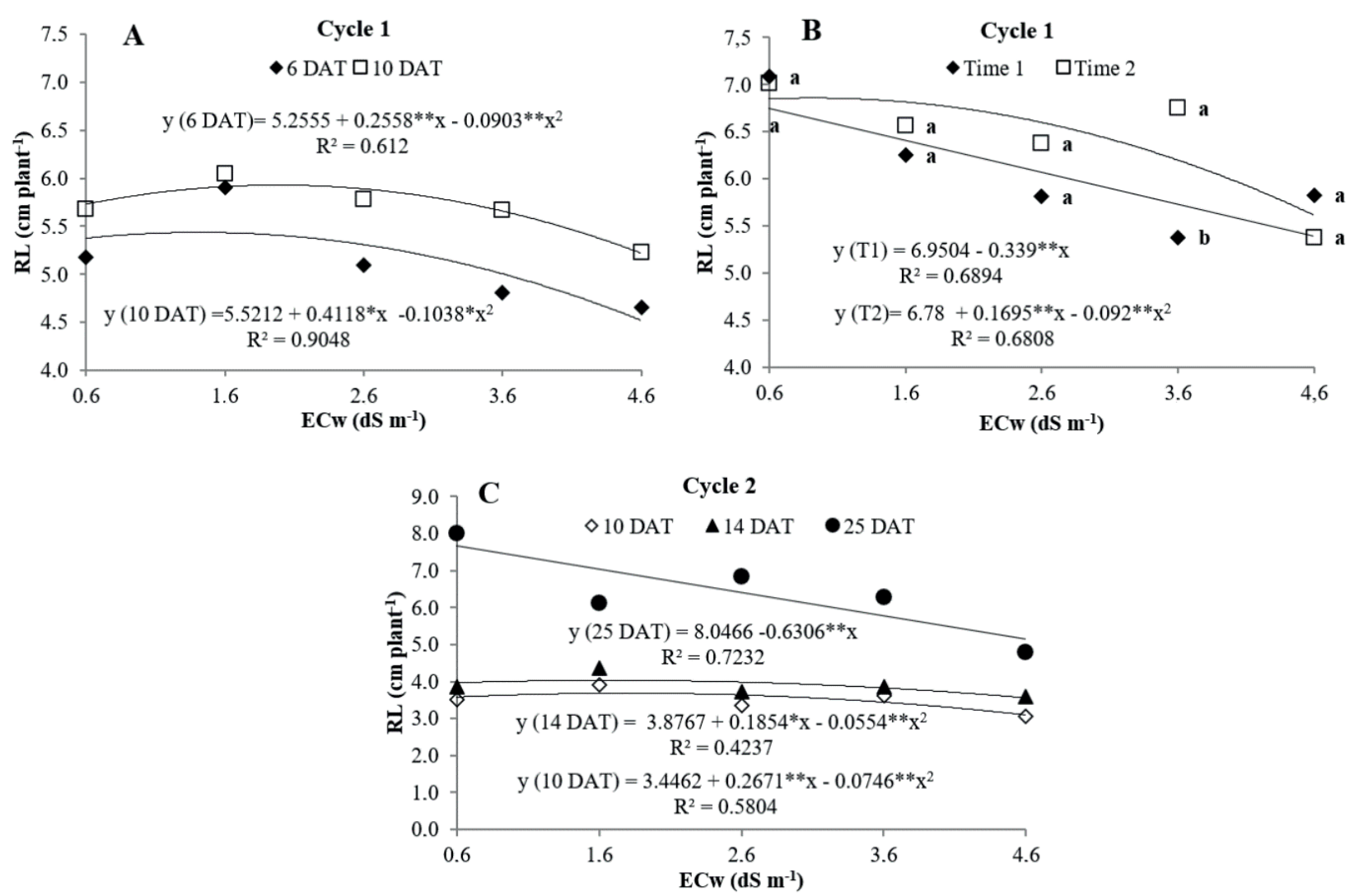

Figure 7. Root length as a function of the isolated effect of salinity (A and C) in cycle 1 and interaction between salinity and nutrient solution circulation time (B) in cycle 2 of the watercress crop.

** and *: significant at 1 and $5 \%$ by the $\mathrm{F}$ test.

\section{Conclusion}

Increasing the water salinity in both cultivation cycles will reduce gas exchanges, stem diameter and root length. The proline content indicated that even under hydroponic conditions, the plants exhibit stress in response to increasing water salinity, regardless of the nutrient solution circulation time. The circulation time of 15 min provided the most satisfactory results for the analyzed variables, in both growing cycles.

\section{Acknowledgments}

Thanks are due to the Coordination for the Improvement of Higher Education Personnel (CAPES) and the Federal University of Ceará.

\section{References}

Albuquerque, J. R. T., Sá, F. V., Oliveira, F. A., Paiva, E. P., Araújo, E. B. G., \& Souto, L. S. (2016). Crescimento inicial e tolerância de cultivares de pepino sob estresse salino. Revista Brasileira de Agricultura Irrigada, 10(2), 486-495. doi: 10.7127/ rbai.v10n200355

Almeida, R. V. A., Aragão, M. F., Sousa, H. G., Bezerra, F. M. S., \& Silva, A. O. (2018). Influência de níveis freáticos nos parâmetros produtivos e fisiológicos da cultura do rabanete. Revista Brasileira de Agricultura Irrigada, 12(5), 2907-2922. doi: 10.7127/rbai. v12n500866

Bates, L. S., Waldren, R. P., \& Teare, J. D. (1973). Rapid determination of free proline for water-stress studies. Plant and Soil, 39(1), 205-207. doi: 10.1007/ BF00018060 
Campos, J. E., Jr., Santos, J. A., Jr., Silva, Ê. F. F., Martins, J. B., \& Rolim, M. M. (2018). Efficiency and water content of arugula under different management of brackish nutritional solutions. Engenharia Agrícola, 38(6), 885-892, 2018. doi: 10.1590/1809-4430-eng. agric.v38n6p885-892/2018

Chiconato, D. A., Sousa, G. S., Jr., Santos, D. M. M., \& Munns, R. (2019). Adaptation of sugarcane plants to saline soil. Environmental and Experimental Botany, 162(1), 201-211. doi: 10.1016/j.envexpbot.2019. 02.021 .

Filgueira, F. A. R. (2012). Novo manual de olericultura: agrotecnologia moderna na produção $e$ comercialização de hortaliças (3a ed.). Viçosa, MG: Editora UFV.

Furlani, P. R. (1998). Instruções para o cultivo de hortaliças de folhas pela técnica de hidroponia NFT. Campinas: IAC.

Gonçalves, E. R., Ferreira, V. M., Silva, J. V., Endres, L., Barbosa, T. P., \& Duarte, W. G. (2010). Trocas gasosas e fluorescência da clorofila a em variedades de cana-de-açúcar submetidas à deficiência hídrica. Revista Brasileira de Engenharia Agrícola $e$ Ambiental, 14(4), 378-386. doi: 10.1590/S141543662010000400006

Hannachi, S., \& Van Labeke, M. C. V. (2018). Salt stress affects germination, seedling growth and physiological responses differentially in eggplant cultivars (Solanum melongena L.). Scientia Horticulturae, 228(1), 56-65. doi: 10.1016/j. scienta.2017.10.002

Lima, L. A., Oliveira, F. A., Alves, R. C., Linhares, P. C. F., Medeiros, A. M. A., \& Bezerra, F. M. (2015). Tolerância da berinjela à salinidade da água de irrigação. Revista Agro@mbiente On-line, 9(1), 2734. doi: 10.18227/1982-8470ragro.v9i1.2202

Lira, R. M., Silva, Ê. F. F., Silva, A. O., Medeiros, P. R. F., Silva, G. F., \& Soares, H. R. (2019). Watercress and chinese cabbage in a hydroponic system using groundwater. Revista Caatinga, 32(4), 1038-1047. doi: 10.1590/1983-21252019v32n420r

Lira, R. M., Silva. E. F. F., Silva, G. F., Soares, H. R., \& Willadino, L. G. (2018). Growth, water consumption and mineral composition of watercress under hydroponic system with brackish water. Horticultura Brasileira, 36(1), 13-19. doi: 10.1590/s0102053620180103

Martinez, H. E. P. (2016). Manual prático de hidroponia. Viçosa, MG: Editora Aprenda Fácil.
Mohammad, M., Shibli, R., \& Ajouni, M. (1998). Tomato root and shoot responses to salt stress under different levels of phosphorus nutrition. Journal of Plant Nutrition, 21(8), 1667-1680. doi: 10.1080/019 04169809365512

Munns, R. (2011). Plant adaptations to salt and water stress: differences and commonalities. Advances in Botanical Research, 57(1), 1-32. doi: 10.1016/B9780-12-387692-8.00001-1

Oliveira, F. A., Sá, F. V., Pereira, F. H., Araújo, F. N., Paiva, E. P., \& Almeida, J. P. N. (2016). Comportamento fisiológico e crescimento de plantas de melancieira sob diferentes concentrações de solução nutritiva. Revista Brasileira de Agricultura Irrigada, 10(1), 439-448. doi: 10.7127/rbai.v10n1 00365

Paulus, D., Dourado, D., Neto, Frizzone, J. A., \& Soares, T. M. (2010). Produção e indicadores fisiológicos de alface sob hidroponia com água salina. Horticultura Brasileira, 28(1), 29-35. doi: 10.1590/S010205362010000100006

Santos, D. P., Santos, C. S., Silva, P. F., Pinheiro, M. P. M. A., \& Santos, J. C. (2016). Crescimento e fitomassa da beterraba sob irrigação suplementar com água de diferentes concentrações salinas. Ceres, 63(4), 509516. doi: 10.1590/0034-737X201663040011

Santos, R. S. S., Dias, N. S., Sousa, O. N., Neto, \& Gurgel, M. T. (2010). Use of the desalted wastewater for lettuce (Lactuca sativa L.) production in NFT hydroponic system. Ciência e Agrotecnologia, 34(4), 983-989. doi: 10.1590/S1413-70542010000400026

Sarabi, B., Bolandnazar, S., Ghaderi, N., \& Ghashghaie, J. (2017). Genotypic differences in physiological and biochemical responses to salinity stress in melon (Cucumis melo L.) plants: prospects for selection of salt tolerant landraces. Plant Physiology and Biochemistry, 119(1), 94-311. doi: 10.1016/j.plaphy. 2017.09.006

Silva, A. O., Soares, T. M., Silva, Ê. F. F., Santos, A. N., \& Klar, A. E. (2012). Consumo hídrico da rúcula em cultivo hidropônico NFT utilizando rejeitos de dessalinizador. Irriga, 17(1), 114-125. doi: 10.15809/ irriga.2012v17n1p114

Silva, F. L. B., Lacerda, C. F., Sousa, G. G., Neves, A. L. R., Silva, G. L., \& Sousa, C. H. (2011). Interação entre salinidade e biofertilizante bovino na cultura do feijão-de-corda. Revista Brasileira de Engenharia Agrícola e Ambiental, 15(4), 383-389. doi: 10.1590/ S1415-43662011000400009 
Silva, F. V., Duarte, S. N., Lima, C. J. G. S., Dias, N. S., Santos, R. S., \& Medeiros, P. R. F. (2013). Cultivo hidropônico de rúcula utilizando solução nutritiva salina. Revista Brasileira de Ciências Agrárias, 8(3), 476-482. doi: 10.5039/agraria.v8i3a1689

Soares, T. M., Duarte, S. N., Silva, Ê. F. F., Melo, R. F., Jorge, C. A., \& Oliveira, A. S. (2009). Experimental structure for evaluation of brackish water use in lettuce hydroponic production. Irriga, 14(1), 102114. doi: 10.15809/irriga.2009v14n1p102-114
Soares, T. M., Duarte, S. N., Silva, E. F. F., Jorge, C. A. (2010). Combinação de águas doce e salobra para produção de alface hidropônica. Revista Brasileira de Engenharia Agrícola e Ambiental, 14(7), 705714. doi: 10.1590/S1415-43662010000700004

Taiz, L., \& Zeiger, E. (2013). Fisiologia vegetal. Porto Alegre: Artmed.

Taiz, L., Zeiger, E., Møller, I. M., \& Murphy, A. (2017). Fisiologia e desenvolvimento vegetal (6a ed.). Porto Alegre: Artmed. 
